\title{
Impact of Metformin and Increased Temperature on Blue Mussels Mytilus edulis - Evidence for Synergism
}

Author(s): Wulan Koagouw and Corina Ciocan

Source: Journal of Shellfish Research, 37(3):467-474.

Published By: National Shellfisheries Association

https://doi.org/10.2983/035.037.0301

URL: http://www.bioone.org/doi/full/10.2983/035.037.0301

BioOne (www.bioone.org) is a nonprofit, online aggregation of core research in the biological, ecological, and environmental sciences. BioOne provides a sustainable online platform for over 170 journals and books published by nonprofit societies, associations, museums, institutions, and presses.

Your use of this PDF, the BioOne Web site, and all posted and associated content indicates your acceptance of BioOne's Terms of Use, available at www.bioone.org/page/terms_of_use.

Usage of BioOne content is strictly limited to personal, educational, and non-commercial use. Commercial inquiries or rights and permissions requests should be directed to the individual publisher as copyright holder. 


\title{
IMPACT OF METFORMIN AND INCREASED TEMPERATURE ON BLUE MUSSELS MYTILUS EDULIS - EVIDENCE FOR SYNERGISM
}

\author{
WULAN KOAGOUW ${ }^{1,2}$ AND CORINA CIOCAN ${ }^{1 *}$ \\ ${ }^{1}$ School of Pharmacy and Biomolecular Sciences, University of Brighton, Lewes Road, Brighton BN2 \\ $4 A T$, United Kingdom; ${ }^{2}$ Bitung Marine Life Conservation Unit, Research Center for Oceanography, \\ Indonesian Institute of Sciences, Jl. Tandurusa Aertembaga Bitung, North Sulawesi, 95227 Indonesia
}

\begin{abstract}
The capability of selected pharmaceuticals to act as nontraditional endocrine disrupting chemicals in the environment has been poorly documented. The widely prescribed antidiabetic metformin has the potential to accumulate and persist in water bodies, with unknown consequences for aquatic biota. This study reports the biological responses of a sentinel organism, common mussel Mytilus edulis, exposed to concentrations of metformin commonly found in the aquatic environment, coupled with heat stress. The results indicate that metformin has the potential to increase the vitellogenin mRNA expression, to inflict severe pathologies of the gonad and to destabilize the lysosomal membrane in the hemocytes. Overall, this article suggests that metformin should be considered an emerging contaminant of concern and further research should focus on its mechanisms of action.
\end{abstract}

KEY WORDS: endocrine disrupting chemicals, high temperature, metformin, Mytilus edulis, vitellogenin

\section{INTRODUCTION}

Water contamination with pharmaceuticals is emerging as a new challenge in clean water legislation. These pollutants are largely untouched through treatment works and are hugely disruptive to aquatic ecosystems. There is a growing body of literature reporting the presence and effects of pharmaceuticals in freshwater environments (Burkina et al. 2015, de Solla et al. 2016, Klaper \& Niemuth 2016, Papageorgiou et al. 2016, Bradley et al. 2017); however studies on marine organisms are limited. Only recently, several articles have reported the impact of selected pharmaceuticals on the physiology and behavior of marine species (Gonzalez-Rey \& Bebianno 2012, Matozzo et al. 2016, Cappello et al. 2017, McCallum et al. 2017). Some pharmaceuticals have unveiled their potential to act as nonclassical endocrine disrupting chemicals (EDCs) (Péry et al. 2008, Mennigen et al. 2010, Gonzalez-Rey \& Bebianno 2012, Niemuth et al. 2014, Dorelle et al. 2017). Endocrine disruption has been recorded mainly in species living close to coastal environments, with most documented effects including imposex and localized population extinction in marine molluscs (Tyler \& Goodhead 2010).

Interestingly, a seasonal variation in the occurrence and concentration of pharmaceuticals in water bodies has been often recorded (Archana et al. 2017), raising the question of cumulative effects of elevated temperature of the surface waters and the putative high levels of pharmaceuticals, during the hot season/summer months. Yang et al. (2017) showed that the overall pharmaceutical levels both in surface water and riverside groundwater are detected at higher concentrations during the dry season.

Data on multi stressor effects on aquatic biota, especially on marine organisms are starting to emerge. Crain et al. (2008) reviewed 171 studies that manipulated two or more stressors in the marine environment and found that the cumulative effects in individual studies were additive $(26 \%)$, synergistic $(36 \%)$, or antagonistic $(38 \%)$. The toxicity of pharmaceutical contaminants

*Corresponding author. E-mail: c.ciocan@brighton.ac.uk DOI: $10.2983 / 035.037 .0301$ is likely to increase with increased temperatures. Gagné et al. (2013) and Negri et al. (2013) highlighted the risk of oxidative alteration, via increased production of reactive oxygen species, in organisms exposed to chemical pollutants along with thermal stress.

Patra et al. (2015) noted that endosulfan is more toxic to silver perch at 30 and $35^{\circ} \mathrm{C}$ exposure, than at 15,20 and $25^{\circ} \mathrm{C}$. Kim et al. (2010) showed that an increase in water temperature is likely to enhance the acute toxicity of the acetaminophen, enrofloxacin, and chlortetracycline, potentially because of alteration in toxicokinetics of chemicals and impact on physiological mechanisms of the organisms.

Metformin, a first line pharmaceutical in the treatment of type 2 diabetes, is among the most prescribed pharmaceutical worldwide (Laak et al. 2014), and one with the highest emission in the environment, on a mass basis. The average concentration of metformin in raw waste waters exceeds the concentrations of other pharmaceuticals by roughly two orders of magnitude (Oosterhuis et al. 2013). Recent studies conducted on US streams (Bradley et al. 2017), waste waters in Greece (Kosma et al. 2015), subarctic locations in Faroe Islands, Iceland, and Greenland (Huber et al. 2016), and freshwater environment in Korea (Ji et al. 2016) and Vietnam (Chau et al. 2015) showed that metformin is one of the 10 most frequently detected designed bioactive contaminants. Data on the levels of metformin and its metabolite, guanylurea, show that the threshold of toxicological concern is exceeded 5-10 times in EU surface waters (European Environment Agency 2010). Aquatic contamination with metformin has been recently documented by Scheurer et al. (2009, 2012), Trautwein and Kümmerer (2011), (2014), Oosterhuis et al. (2013), and Niemuth et al. (2014). Still, despite alarming concentrations being frequently detected $(0.06-129 \mu \mathrm{g} / \mathrm{L})$, only few studies have investigated the ecotoxicological effect of metformin on aquatic organisms.

This article reports for the first time the cumulative effects of temperature and the pharmaceutical metformin in the blue mussels Mytilus edulis after a short exposure under laboratory conditions. The experimental design aims to quantify the biological responses of mussels using the Q10 temperature 
coefficient, as suggested by Jansen et al. (2007), taking into consideration the thermal stress experienced by intertidal mussels alternating between aerial and aquatic habitats. Three putative target genes, estrogen receptor 2 (ER2), vitelline envelope zona pellucida domain 9 (V9), and vitellogenin (VTG) have been selected to assess the potential endocrine disrupting end point response, whereas lysosomal membrane stability and gonad histopathology have been chosen as indicators of immune competence/reproductive impairment-related effects.

As inhabitants of the intertidal zone, blue mussels Mytilus edulis are commonly used as a bioindicator species because of their propensity to concentrate contaminants. They are also widely used in ecotoxicology studies worldwide (Cubero-Leon \& Ciocan 2013), conducted in field with native (Hagger et al. 2010) or caged mussels (Cappello et al. 2015, Maisano et al. 2017), and carried out under controlled laboratory conditions (Giannetto et al. 2015).

\section{MATERIALS AND METHODS}

\section{Sample Collection}

Blue mussels Mytilus edulis were collected from Hove beach, East Sussex, UK (50 49' 25.4" N $0^{\circ} 10^{\prime} 19.8^{\prime \prime} \mathrm{W}$ ) in January 2016. Individuals of similar size $(35-50 \mathrm{~mm})$ were collected manually at low tide. Mussels were kept on ice and transferred immediately to the exposure room. After collection, all mussels were cleaned and placed in a cooling system with artificial seawater (Instant Ocean Sea Salt) prepared as per manufacturer instruction. All mussels were acclimatized at $10 \pm 1^{\circ} \mathrm{C}$ for 6 days before exposures.

\section{Exposure Conditions}

Mussels were exposed for 7 days to cumulative effects of metformin and temperature, under controlled laboratory conditions. Metformin stock solution was prepared by dissolving $12 \mathrm{mg}$ metformin hydrochloride (Sigma-Aldrich) to $1 \mathrm{~L}$ reverse osmosis water. This stock solution was used to spike the exposure tanks with the final concentration of $40 \mu \mathrm{g} / \mathrm{L}$ metformin in artificial seawater, the environmentally relevant concentration used in previous studies by Niemuth et al. (2014) and Niemuth and Klaper (2015). Exposure groups were as follows: C10 (control, water at $10^{\circ} \mathrm{C}$ ), $M 10$ (water at $10^{\circ} \mathrm{C}$, plus metformin $40 \mu \mathrm{g} / \mathrm{L}$ ), $C 20$ (water at $20^{\circ} \mathrm{C}$ ), and $M 20$ (water at $20^{\circ} \mathrm{C}$, plus metformin $\left.40 \mu \mathrm{g} / \mathrm{L}\right)$. The low temperature was maintained with a cooling system at $10 \pm 1{ }^{\circ} \mathrm{C}$ (similar to seawater temperature at sampling time), whereas high temperature was achieved by placing the tanks in a room with controlled temperature. The water was changed and respiked with metformin every 2 days to allow $500 \mathrm{~mL}$ water/mussel $/ 48 \mathrm{~h}$ (three mussels per 2-L tank, six replicates). Mussels were unfed, oxygen was supplied on a constant flow, and salinity, $\mathrm{pH}$, and a 12-h light/dark regime were maintained consistent throughout the experiment. Seventeen mussels in each exposure group were used for analyses.

\section{Species Confirmation}

Species confirmation was performed by polymerase chain reaction (PCR) amplification of the Glu gene using primers Me15 and Me16 as described by Inoue et al. (1995). Primer sequences are shown in Table 1. The expected amplicons were a $180 \mathrm{bp}$ band for Mytilus edulis and a $126 \mathrm{bp}$ band for Mytilus galloprovincialis.

\section{Neutral Red Retention Time (NRRT) Assay}

At the end of the experimental exposure, hemolymph of five mussels from each group was extracted for cytological evaluation of lysosomal membrane stability using NRRT assay. The procedure was adapted from Lowe and Pipe (1994) and Mamaca et al. (2005) with some modifications. A dye stock solution was prepared by dissolving $28.8 \mathrm{mg}$ Neutral Red (Sigma-Aldrich) in $1 \mathrm{~mL}$ of dimethyl sulfoxide. A working solution was then prepared by diluting $2 \mu \mathrm{L}$ of stock solution with $1 \mathrm{~mL}$ of physiological saline solution $(4.77 \mathrm{~g} / \mathrm{L}$ HEPES, $25.48 \mathrm{~g} / \mathrm{L} \mathrm{NaCl}, 13.06 \mathrm{~g} / \mathrm{L} \mathrm{MgSO}_{4}, 0.75 \mathrm{~g} / \mathrm{L} \mathrm{KCl}$, and $1.47 \mathrm{~g} / \mathrm{L}$ $\mathrm{CaCl}_{2}$ to a final volume of $1 \mathrm{~L}$ reverse osmosis water; $\mathrm{pH}$ 7.3).

A volume of $0.2 \mathrm{~mL}$ haemolymph was withdrawn from the adductor muscle using a $2 \mathrm{~mL}$ syringe with $0.2 \mathrm{~mL}$ of physiological saline solution. A volume of $30 \mu \mathrm{L}$ of haemolymph-saline mixture was transferred onto the poly-L-lysine coated microscope slide. Slides were placed in a light proof humidity chamber for $15 \mathrm{~min}$ at room temperature. Neutral red working solution $(30 \mu \mathrm{L})$ was added to the area containing the attached cells and a cover slip was applied. After 15 min of incubation, slides were examined using light microscopy $(40 \times / 100 \times)$ and then checked at 15-min intervals.

TABLE 1.

Primers sequences used for the molecular analysis.

\begin{tabular}{|c|c|c|}
\hline Primer name & Forward primer & Reverse primer \\
\hline \multicolumn{3}{|l|}{$G l u$ gene $\left(5^{\prime}-3^{\prime}\right)$} \\
\hline Me15 & CCAGTATACAAACCTGTGAAGA & $\mathrm{N} / \mathrm{A}$ \\
\hline Me16 & $\mathrm{N} / \mathrm{A}$ & TGTTGTCTTAATAGGTTTGTAAGA \\
\hline \multicolumn{3}{|c|}{ Housekeeping gene } \\
\hline $18 S \operatorname{RNA}$ & GTGCTCTTGACTGAGTGTCTCG & CGAGGTCCTATTCCATTATTCC \\
\hline EF1 & CACCACGAGTCTCTCCCAGA & GCTGTCACCACAGACCATTCC \\
\hline \multicolumn{3}{|l|}{ Target gene } \\
\hline$E R 2$ & GGAACACAAAGAAAAGAAAGGAAG & GCTGGATTAGGACTGCCACTTG \\
\hline$V 9$ & TTCTGGACGAAATGCTAATGTGA & GGATTGAGCGTGACGAGACC \\
\hline$V T G$ & GGACCTCCACCAGTGCTAATCC & ATCTCAGCGGTTCCGACTGC \\
\hline
\end{tabular}


Histological Analysis of Mussel Gonads

Twelve mussels from each group were dissected after exposures and fragments were stored for histological and molecular analysis. Histological analysis was performed as described by Ciocan et al. (2010) to determine the reproductive stage and highlight potential histopathology conditions. Stained tissue sections (hematoxylin, eosin) were examined under light microscopy $(40 \times / 100 \times)$. The histopathological condition of each sample was recorded and micrographs corresponding to these conditions were taken.

Quantitative Real-time PCR Analysis of ER2, V9, and VTG messenger RNA (mRNA) Expression

Small fragments $(0.5 \times 0.5 \mathrm{~cm})$ of mussel gonad $(12$ mussels from each treatment group) were kept in tubes with RNALater (Invitrogen). Molecular analysis was adapted from Ciocan et al. (2010) to examine the effects of exposures on mRNA expression of ER2, $V 9$, and $V T G$ in mussel gonad.

Total RNA was extracted from gonad tissue using High Pure RNA Tissue Kit (Roche) following the manufacturer instruction. The concentration of extracted RNA was measured using a Qubit Fluorometer (manufacturer instruction). RevertAid First Strand complementary DNA (cDNA) Synthesis Kit (ThermoFisher) was used to carry out reverse transcription of total RNA. Concentration of first strand cDNA was also recorded using Qubit dsDNA Assay Kit (ThermoFisher).

All quantitative real-time PCR reactions were performed in duplicate using FastStart Essential DNA Green Master (Roche) following the given instruction by manufacturer. To determine the specificity of target cDNA amplification, a control lacking cDNA was included in each quantitative polymerase chain reaction run. Amplification reactions were run in a Roche LightCycler Nano System with the following parameters: $95^{\circ} \mathrm{C}$ for $10 \mathrm{~min}, 45$ cycles of $20 \mathrm{sec}$ at $95^{\circ} \mathrm{C}, 20 \mathrm{sec}$ at $48-60^{\circ} \mathrm{C}$, and $20 \mathrm{sec}$ at $72^{\circ} \mathrm{C}$. Melting curves were determined to analyze the specificity of the reaction and identify the presence of primer dimer by holding the reaction at $65^{\circ} \mathrm{C}$ for $1 \mathrm{~min}$ and $95^{\circ} \mathrm{C}$ for $1 \mathrm{~min}$. Housekeeping genes $18 \mathrm{~S}$ ribosomal RNA (18S rRNA) and elongation factor-1 alpha (EF1) were used as the internal control genes. Primer sequences used in quantitative real-time PCR analysis are shown in Table 1.

\section{Data Analysis}

Raw data (cycle quantification) from quantitative real-time PCR analysis of each ER2, V9, and VTG mRNA expression was normalized using the average cycle quantification of housekeeping genes, $18 S$ rRNA and EF1, corresponding to each sample. The calculation of relative changes in target genes expression determined from quantitative real time PCR followed the comparative $2^{-\Delta \Delta C T}$ method as described by Livak and Schmittgen (2001).

Statistical analysis was carried out using GraphPad Prism 7. One-way analysis of variance was performed, followed by Tukey's multiple comparison test to identify the difference between the groups with $P<0.05$.

\section{RESULTS}

\section{Species Confirmation}

Mussel species Mytilus edulis was confirmed by amplification of the Glu gene, following Inoue et al. (1995) protocol.

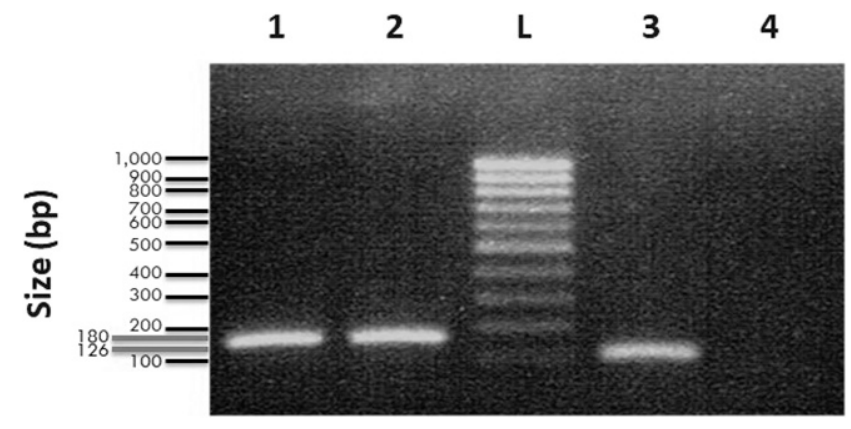

Figure 1. Results of Glu gene amplification visualized on $0.8 \%$ agarose gel electrophoresis. Lanes 1 and 2, samples confirmed as Mytilus edulis (180 bp); lane L, exACTGene 100 bp DNA ladder; lane 3, Mytilus galloprovincialis (126 bp); and lane 4, negative control.

Figure 1 shows the result of $G l u$ gene amplification visualized on $0.8 \%$ agarose gel electrophoresis. Analyzed samples (two random samples from control and exposed groups) exhibited a single band size $180 \mathrm{bp}$, corresponding to Mytilus edulis.

\section{Neutral Red Retention Time Assay}

A statistically significant difference in NRRT was observed between the $\mathrm{C} 10$ and $\mathrm{C} 20$ groups and M10 and M20 treatments (Fig. 2). Nevertheless, the increased temperature failed to elicit a response in lysosomal membrane stability (C10 compared with $\mathrm{C} 20$, and M10 compared with M20). Exposed groups (M10 and M20) showed a decline in NRRT compared with C10 and C20 groups, regardless of the temperature exposure (Fig. 2).

\section{Histological Analysis}

At the end of the experiment, the mussels showed an overall sex ratio of 1:1. Control mussel gonads did not exhibit any pathology (Fig. 3). Follicle dilation and atresia are the most

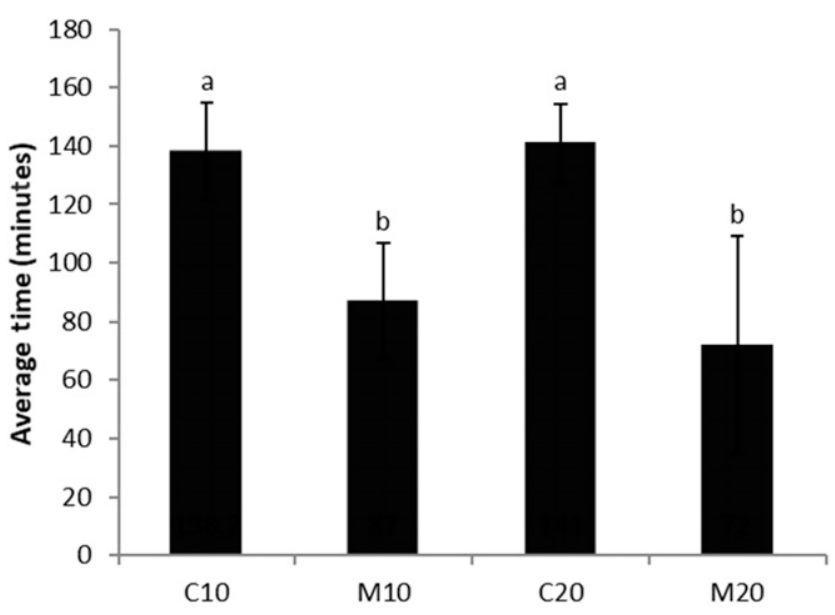

Figure 2. Summary of NRRT in lysosomes from mussel hemocytes $(n=5)$. $\mathrm{C} 10$, control group, seawater at $10^{\circ} \mathrm{C} ; \mathrm{M10}$, group exposed to metformin $40 \mu \mathrm{g} / \mathrm{L}$, seawater at $10^{\circ} \mathrm{C}$; $\mathrm{C} 20$, no metformin, seawater at $20^{\circ} \mathrm{C}$; $\mathrm{M20}$, group exposed to metformin $40 \mu \mathrm{g} / \mathrm{L}$, seawater at $20^{\circ} \mathrm{C}$. Mean data; bars represent $\mathrm{SD}$. Bars with a different letter represent statistically significant different set of data $(P<0.05)$. Groups $\mathrm{C} 10$ and $\mathrm{C20}$ differ significantly from groups M10 and M20. 
observed pathological conditions in mussels exposed to high temperature (C20 and M20). Follicle degeneration and gamete degradation are observed in mussels exposed to metformin (M10 and M20). Interestingly, the results indicate that both metformin and high temperature exposures are more likely to impact female gonads (Fig. 4).

\section{Quantitative Real-time PCR Analysis of ER2, V9, and VTG mRNA Expression}

Variations in the $E R 2, V 9$, and $V T G$ mRNA expression calculated as fold changes compared with control group $\mathrm{C} 10$ are displayed in Figure 5. The expression of ER2 mRNA - is upregulated in high temperature group regardless of the presence of metformin (Fig. 5A). The expression of $V 9 \mathrm{mRNA}$ is possibly suppressed by both high temperature and metformin exposures, although the results are not statistically significant. By contrast, $V T G$ mRNA expression is statistically significantly upregulated in all exposed groups (Fig. 5B, C).

\section{DISCUSSION}

\section{Neutral Red Retention Time Assay}

Mussels are known to respond to environmental stressors by altering metabolic rates and enzyme activities (Widdows 1973). Lysosomal membrane stability is a very sensitive indicator of cellular damage, as lysosomes constitute main cellular sites for sequestration and detoxification of metal and organic contaminants (Dailianis et al. 2003). Thus, the response to the uptake of any contaminant may lead to lysosomal membrane damage, a subcellular pathological reaction linked to augmented autophagic sequestration of cellular components (Sforzini et al. 2018). Therefore, the NRRT assay measures the ability of cytological processes to adjust to stress conditions (Lowe \& Pipe 1994).

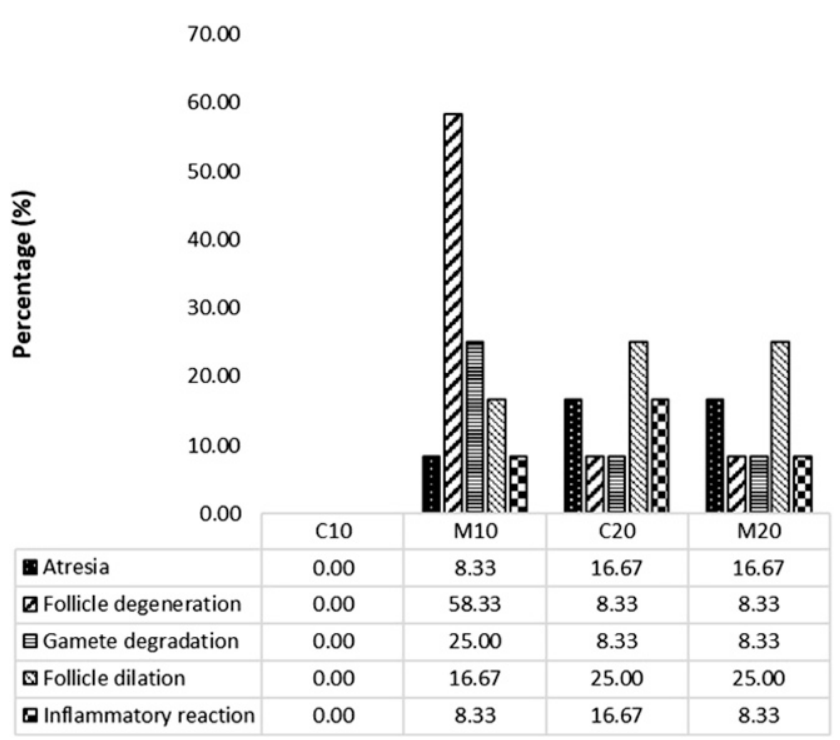

Figure 3. Summary of histopathological condition observed in mussel gonadal tissue $(n=12) . \mathrm{C10}$, control group, seawater at $10^{\circ} \mathrm{C}$; $\mathrm{M10}$, group exposed to metformin $40 \mu \mathrm{g} / \mathrm{L}$, seawater at $10^{\circ} \mathrm{C}$; $\mathrm{C20}$, no metformin, seawater at $20^{\circ} \mathrm{C} ; \mathrm{M20}$, group exposed to metformin $40 \mu \mathrm{g} / \mathrm{L}$, seawater at $20^{\circ} \mathrm{C}$.
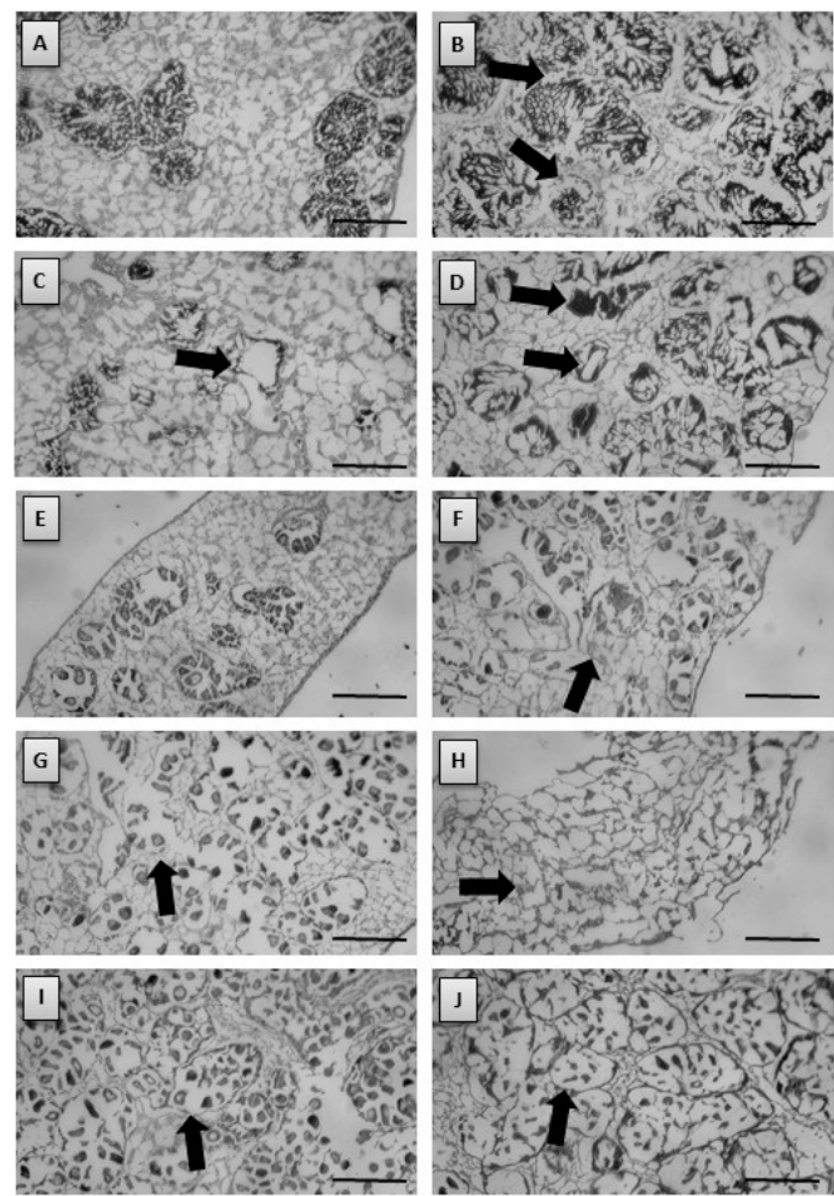

Figure 4. Micrographs showing normal and pathological conditions in gonad tissue. (A) Normal histology, male; (B) inflammatory reaction, male; (C) follicle dilation, male; (D) follicle degeneration, male; (E) normal histology, female; (F) inflammatory reaction, female; (G) follicle dilation, female; $(\mathrm{H})$ follicle degeneration, female; (I) atresia, female; and (J) gamete degradation, female. Arrows point to each pathological condition. Scale bar $=200 \mu \mathrm{m}$.

According to the threshold values of NRRT assay in marine bivalves set up by Moore et al. (2006), control mussels in this present study (C10 and C20) can be considered healthy, whereas the metformin exposed groups are categorized as stressed, but not severe. To our knowledge, this is the first record of a 6-day exposure of adult mussels to environmentally relevant concentrations of metformin, resulting in a drastic decrease in NRRT in hemocytes (approximately $45 \%$ reduction). Mussels exposed to metformin and thermal stress showed typical signs of stress response, such as remarkable lysosomal membrane destabilization. Usually, these stress signals are accompanied by mobilization of neutral lipids and enhanced glycolysis, with deleterious consequences on growth and reproduction, as shown by Marigomez et al. (2017).

\section{Histological Analysis}

The mussels used in this study were in the incipient stages of gonad development. Following experimental exposure, pathologies such as follicle dilation and atresia (Fig. 4C, G, I) were prevalent in mussel gonads exposed to 


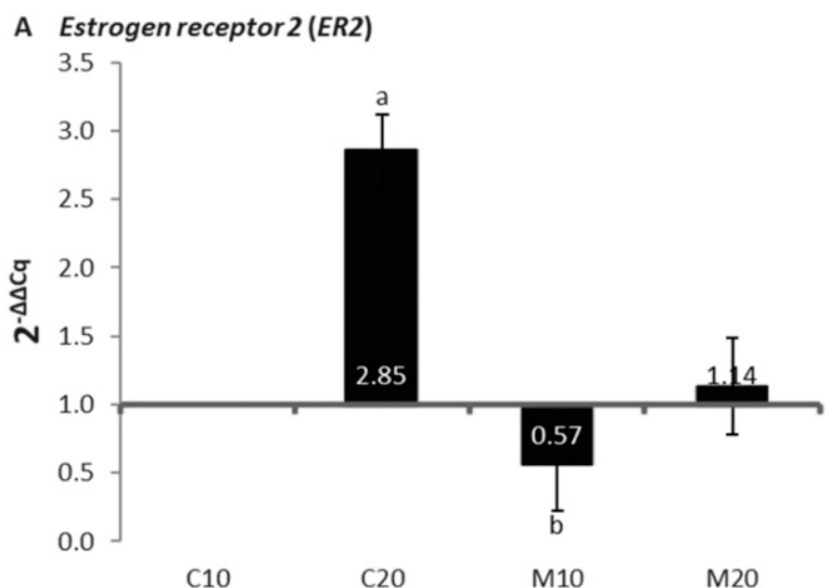

B Vitelline envelope zona pellucida domain 9 (V9)

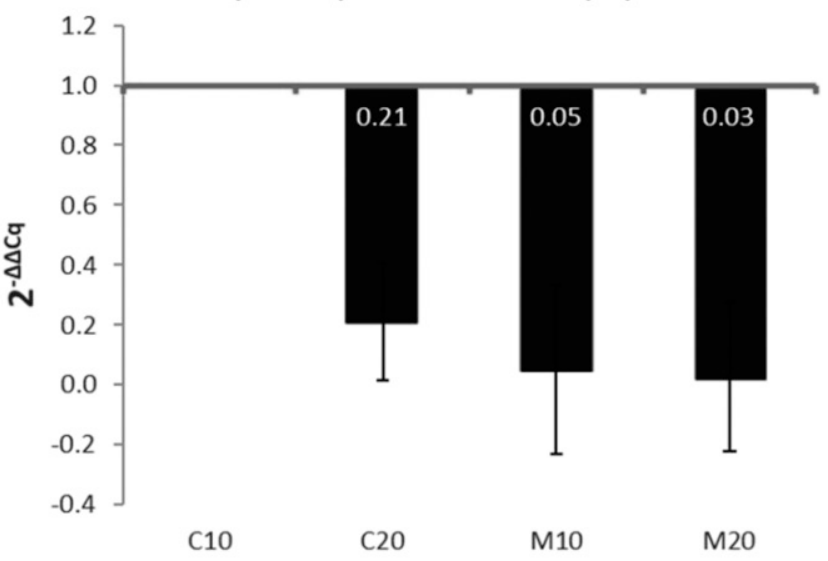

C Vitellogenin (VTG)

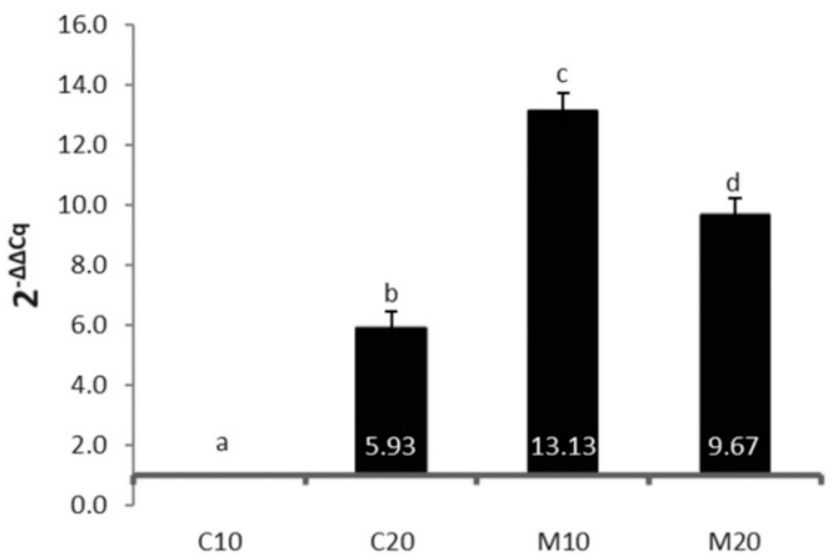

Figure 5. Summary of $E R 2$ (A), $V 9$ (B), and $V T G(C)$ mRNA expression compared with control group (C10) in mussel gonad $(n=12)$. C10, control group, seawater at $10^{\circ} \mathrm{C} ; \mathrm{M10}$, group exposed to metformin $40 \mu \mathrm{g} / \mathrm{L}$, seawater at $10^{\circ} \mathrm{C} ; \mathrm{C20}$, no metformin, seawater at $20^{\circ} \mathrm{C} ; \mathrm{M} 20$, group exposed to metformin $40 \mu \mathrm{g} / \mathrm{L}$, seawater at $20^{\circ} \mathrm{C}$. Bars represent SEM. Bars with a different letter represent statistically significant different set of data $(P<0.05)$.

high temperature (C20 and M20). Gosling (2015) states that temperature is the exogenous factor that most likely has an impact on gametogenesis in bivalves, with Bayne (1975) recording a linear relationship between the rate of temperature change and gametogenesis in Mytilus edulis.

Atresia of oocytes usually occurs at the end of vitellogenesis, but hydrolytic enzymes released from lysed oocytes also may affect previtellogenic oocytes (Beninger \& Le Pennec 2006). It is suggested that at the time of the lowest level of energy reserves in adductor muscle, these lysed oocytes have the function to supply metabolic substrates for energy production (Beninger \& Le Pennec 2006). Present findings indicate that temperature exposure may trigger oocyte atresia by increasing the rate of vitellogenesis. Extensive oocyte atresia, a symptom of reproductive impairment as a result of an environmental insult, would provide a surplus energy source to cope with extra metabolic demand, at the expense of successful spawning and fertilization.

Recent studies have reported that many marine contaminants have a powerful impact on mussel gametogenesis (Zorita et al. 2006, Bacchetta \& Mantecca 2009, Ciocan et al. 2010, Cubero-Leon et al. 2010, Iyapparaj et al. 2013). This article shows that follicle degeneration (Fig. 4D, H), gamete degradation (Fig. 4J), and follicle dilation (Fig. 4A, C, G) are the most common pathological conditions in mussels exposed to metformin (M10 and M20). These observed effects may lead to disruptions in the reproduction process, resulting in timelimited survival, as demonstrated previously by Mugica et al. (2015). Furthermore, gamete degradation may generate gamete incompatibility, which can result in a mismatch between ova and sperm recognition proteins (Gosling 2015).

A recent study by Niemuth and Klaper (2015) showed that metformin induced intersex in fathead minnow Pimephales promelas males, after exposure to environmentally relevant concentrations. The present article provides evidence that same low levels of metformin in the seawater $(40 \mu \mathrm{g} / \mathrm{L})$ are potent enough to initiate gonad pathologies in the blue mussel, Mytilus edulis. Interestingly, data show that both metformin and high temperature exposures are more likely to affect female mussels. Cappello et al. (2017) also found that drospirenone, a progestine with pharmacological mechanisms of action like progesterone, induces histological changes mainly in female mussel gonads.

\section{Quantitative Real-time PCR Analysis of ER2, V9, and VTG mRNA Expression}

Quantitative PCR analysis highlights the up regulated expression of the steroid receptor, ER2, in high temperature groups (C20 and M20), showing a 2.85-fold change compared with control group $\mathrm{C} 10$ (Fig. 5A). As steroid receptors are considered estrogen specific biomarker genes, these results clearly suggest that mussel gametogenesis is affected even after short exposure to high temperatures. By contrast, mussels exposed to metformin at $10^{\circ} \mathrm{C}$ show a slight downregulation of ER2 mRNA expression compared with control group C10 (Fig. 5A), although not statistically significant. The existence of natural variation of $E R 2$ should also be taken into account, as reported by Ciocan et al. (2010).

Egg yolk related proteins and associated gene expression have been recently shown to decrease after exposure to heavy metals (Gerbron et al. 2015). The precise underlying mechanism resulting in the variation of expression of those transcripts is unclear because of the ongoing debate surrounding the presence and/or function of steroid hormones in bivalves 
(Scott 2012). Both $V 9$ and $E R 2$, as well as $V T G$, have previously been identified as upregulated in mussels (Ciocan et al. 2010, Ciocan et al. 2011, Nagasawa et al. 2015), scallop (Osada et al. 2004), and oyster (Andrew et al. 2010, Ni et al. 2014) exposed to estrogens under laboratory conditions, and in the clam Scrobicularia plana exhibiting intersex conditions (Ciocan et al. 2012).

In this study, mussels exposed to metformin and high temperature display a downregulation, although not statistically significant, of $V 9 \mathrm{mRNA}$ expression, in all exposed groups compared with control group (Fig. 5B). By contrast, VTG mRNA expression is upregulated in all treatment groups $(\mathrm{C} 20$, M10, and M20), showing a statistically significant increase compared with the control (Fig. 5C).

Despite the fact that metformin is not considered a classical EDC, the results presented herein suggest that some pharmaceutical compounds, such as metformin, have the potential to impact the reproductive capacity of marine mussels, by acting as a nontraditional endocrine disruptor. Metformin, a traditional pharmacological activator of AMP-activated protein kinase is potentially able to impact the development and maintenance of reproductive function through inhibiting progesterone receptor function (Wu et al. 2011). In mammals, metformin treatment has been shown to directly inhibit ovarian steroidogenesis (Rice et al. 2009).

\section{CONCLUSION}

In summary, this study shows for the first time that the antidiabetic pharmaceutical, metformin, alone or coupled with high temperature, can alter the immune response in blue mussels, initiate pathological conditions in gonad, including gamete degeneration and atresia, and upregulate $V T G$ mRNA expression up to 13 -fold compared with the control group. These findings suggest the potential of metformin to act as nonclassical EDCs in the environment, and further investigations are needed to elucidate the mechanism of action.

\section{ACKNOWLEDGMENTS}

Profound gratitude is expressed to Darren McCabe, Anna Blunden, and James Bovington for their supportive technical assistance throughout the research. This work was supported by Chevening Fellowships, the UK government's global scholarship programme, funded by the Foreign and Commonwealth Office (FCO) and partner organisations.

\section{LITERATURE CITED}

Andrew, M. N., W. A. O'Connor, R. H. Dunstan \& G. R. MacFarlane. 2010. Exposure to $17 \alpha$-ethynylestradiol causes dose and temporally dependent changes in intersex, females and vitellogenin production in the Sydney rock oyster. Ecotoxicology 19:1440-1451.

Archana, G., R. Dhodapkar \& A. Kumar. 2017. Ecotoxicological risk assessment and seasonal variation of some pharmaceuticals and personal care products in the sewage treatment plant and surface water bodies (lakes). Environ. Monit. Assess. 189:446.

Bacchetta, R. \& P. Mantecca. 2009. DDT polluted meltwater affects reproduction in the mussel Dreissena polymorpha. Chemosphere 76:1380-1385.

Bayne, B. L. 1975. Reproduction in bivalve molluscs under environmental stress. In: Vernberg, F. J. editor. Physiological ecology of estuarine organisms. Columbia, SC: University of South Carolina Press. pp. 259-277.

Beninger, P. G. \& M. Le Pennec. 2006. Structure and function in scallops. In: Shumway, S. E. \& G. J. Parsons, editors. Scallops: biology, ecology and aquaculture, $2^{\text {nd }}$ edition. Boston, MA: Elsevier Science. pp. 123-127.

Bradley, P. M., C. A. Journey, K. M. Romanok, L. B. Barber, H. T. Buxton, W. T. Foreman, E. T. Furlong, S. T. Glassmeyer, M. L. Hladik, L. R. Iwanowicz, D. K. Jones, D. W. Kolpin, K. M. Kuivila, K. A. Loftin, M. A. Mills, M. T. Meyer, J. L. Orlando, T. J. Reilly, K. L. Smalling \& D. L. Villeneuve. 2017. Expanded target-chemical analysis reveals extensive mixed organic-contaminant exposure in US streams. Environ. Sci. Technol. 51:4792-4802.

Burkina, V., V. Zlabek \& G. Zamaratskaia. 2015. Effects of pharmaceuticals present in aquatic environment on Phase I metabolism in fish. Environ. Toxicol. Pharmacol. 40:430-444.

Cappello, T., D. Fernandes, M. Maisano, A. Casano, M. Bonastre, M. J. Bebianno, A. Mauceri, S. Fasulo \& C. Porte. 2017. Sex steroids and metabolic responses in mussels Mytilus galloprovincialis exposed to drospirenone. Ecotoxicol. Environ. Saf. 143:166-172.

Cappello, T., M. Maisano, A. Giannetto, V. Parrino, A. Mauceri \& S. Fasulo. 2015. Neurotoxicological effects on marine mussel Mytilus galloprovincialis caged at petrochemical contaminated areas (eastern Sicily, Italy): H-1 NMR and immunohistochemical assays. Comp. Biochem. Physiol. C Toxicol. Pharmacol. 169:7-15.
Chau, H. T. C., K. Kadokami, H. T. Duong, L. Kong, T. T. Nguyen, T. Q. Nguyen \& Y. Ito. 2015. Occurrence of 1153 organic micropollutants in the aquatic environment of Vietnam. Environ. Sci. Pollut. Res. Int. 25:7147-7156.

Ciocan, C., E. Cubero-Leon, M. Peck, W. J. Langston, N. Pope, C. Minier \& J. M. Rotchell. 2012. Intersex in Scrobicularia plana: transcriptomic analysis reveals novel genes involved in endocrine disruption. Environ. Sci. Technol. 46:12936-12942.

Ciocan, C. M., E. Cubero-Leon, C. Minier \& J. M. Rotchell. 2011. Identification of reproduction-specific genes associated with maturation and estrogen exposure in a marine bivalve Mytilus edulis. PLoS One 6:e22326.

Ciocan, C. M., E. Cubero-Leon, A. M. Puinean, E. M. Hill, C. Minier, M. Osada, K. Fenlon \& J. M. Rotchell. 2010. Effects of estrogen exposure in mussels, Mytilus edulis, at different stages of gametogenesis. Environ. Pollut. 158:2977-2984.

Crain, C. M., K. Kroeker \& B. S. Halpern. 2008. Interactive and cumulative effects of multiple human stressors in marine systems. Ecol. Lett. 11:1304-1315.

Cubero-Leon, E. \& C. M. Ciocan. 2013. Mussels as a tool to monitor pollution. In: Nowak, J. \& M. Kozlowski, editors. Mussels: ecology, life habits and control. New York, NY: Nova Science Publishers, Inc. pp. 77-99.

Cubero-Leon, E., C. M. Ciocan, E. M. Hill, M. Osada, M. Kishida, N. Itoh, R. Kondo, C. Minier \& J. M. Rotchell. 2010. Estrogens disrupt serotonin receptor and cyclooxygenase mRNA expression in the gonads of mussels (Mytilus edulis). Aquat. Toxicol. 98:178-187.

Dailianis, S., G. P. Domouhtsidou, E. Raftopoulou, M. Kaloyianni \& V. K. Dimitriadis. 2003. Evaluation of neutral red retention assay, micronucleus test, acetylcholinesterase activity and a signal transduction molecule (cAMP) in tissues of Mytilus galloprovincialis (L.), in pollution monitoring. Mar. Environ. Res. 56:443-470.

de Solla, S. R., E. A. M. Gilroy, J. S. Klinck, L. E. King, R. McInnis, J. Struger, S. M. Backus \& P. L. Gillis. 2016. Bioaccumulation of pharmaceuticals and personal care products in the unionid mussel Lasmigona costata in a river receiving wastewater effluent. Chemosphere 146:486-496. 
Dorelle, L. S., R. H. Da Cuña, G. Rey Vázquez, C. Höcht, A. Shimizu, G. Genovese \& F. L. Lo Nostro. 2017. The SSRI fluoxetine exhibits mild effects on the reproductive axis in the cichlid fish Cichlasoma dimerus (Teleostei, Cichliformes). Chemosphere 171:370-378.

European Environment Agency. 2010. EEA technical report. Luxembourg: European Environment Agency.

Gagné, F., J. Auclair, P. Turcotte \& C. Gagnon. 2013. Sublethal effects of silver nanoparticles and dissolved silver in freshwater mussels. $J$. Toxicol. Environ. Health A 76:479-490.

Gerbron, M., P. Geraudie, B. Xuereb, S. Marie \& C. Minier. 2015. In vitro and in vivo studies of the endocrine disrupting potency of cadmium in roach (Rutilus rutilus) liver. Mar. Pollut. Bull. 95:582-589.

Giannetto, A., M. Maisano, T. Cappello, S. Oliva, V. Parrino, A. Natalotto, G. De Marco, C. Barberi, O. Romeo, A. Mauceri \& S. Fasulo. 2015. Hypoxia-inducible factor $\alpha$ and hif-prolyl hydroxylase characterization and gene expression in short-time air-exposed Mytilus galloprovincialis. Mar. Biotechnol. (NY) 17:768-781.

Gonzalez-Rey, M. \& M. J. Bebianno. 2012. Does non-steroidal antiinflammatory (NSAID) ibuprofen induce antioxidant stress and endocrine disruption in mussel Mytilus galloprovincialis? Environ. Toxicol. Pharmacol. 33:361-371.

Gosling, E. 2015. Marine bivalve molluscs. Hoboken, NJ: WileyBlackwell.

Hagger, J. A., D. Lowe, A. Dissanayake, M. B. Jones \& T. S. Galloway. 2010. The influence of seasonality on biomarker responses in Mytilus edulis. Ecotoxicology 19:953-962.

Huber, S., M. Remberger, L. Kaj, M. Schlabach, H. Ó. Jörundsdóttir, J. Vester, M. Arnórsson, I. Mortensen, R. Schwartson \& M. Dam. 2016. A first screening and risk assessment of pharmaceuticals and additives in personal care products in waste water, sludge, recipient water and sediment from Faroe Islands, Iceland and Greenland. Sci. Total Environ. 562:13-25.

Inoue, K., J. H. Waite, M. Matsuoka, S. Odo \& S. Harayama. 1995. Interspecific variations in adhesive protein sequences of Mytilus edulis, M. galloprovincialis, and M. trossulus. Biol. Bull. 189:370-375.

Iyapparaj, P., P. Revathi, R. Ramasubburayan, S. Prakash, P. Anantharaman, G. Immanuel \& A. Palavesam. 2013. Antifouling activity of the methanolic extract of Syringodium isoetifolium, and its toxicity relative to tributyltin on the ovarian development of brown mussel Perna indica. Ecotoxicol. Environ. Saf. 89:231-238.

Jansen, J. M., A. E. Pronker, S. Kube, A. Sokolowski, J. C. Sola, M. A. Marquiegui, D. Schiedek, S. Wendelaar Bonga, M. Wolowicz \& H. Hummel. 2007. Geographic and seasonal patterns and limits on the adaptive response to temperature of European Mytilus spp. and Macoma balthica populations. Oecologia 154:23-34.

Ji, K., E. J. Han, S. Back, J. Park, J. Ryu \& K. Choi. 2016. Prioritizing human pharmaceuticals for ecological risks in the freshwater environment of Korea. Environ. Toxicol. Chem. 35:1028-1036.

Kim, J., J. Park, P.-G. Kim, C. Lee, K. Choi \& K. Choi. 2010. Implication of global environmental changes on chemical toxicityeffect of water temperature, $\mathrm{pH}$, and ultraviolet $\mathrm{B}$ irradiation on acute toxicity of several pharmaceuticals in Daphnia magna. Ecotoxicology 19:662-669.

Klaper, R. D. \& N. J. Niemuth. 2016. On the unexpected reproductive impacts of metformin: a need for support and new directions for the evaluation of the impacts of pharmaceuticals in the environment. Chemosphere 165:570-574.

Kosma, C. I., D. A. Lambropoulou \& T. A. Albanis. 2015. Comprehensive study of the antidiabetic drug metformin and its transformation product guanylurea in Greek wastewaters. Water Res. 70:436-448.

Laak, T. L., P. J. F. Kooij, H. Tolkamp \& J. Hofman. 2014. Different compositions of pharmaceuticals in Dutch and Belgian rivers explained by consumption patterns and treatment efficiency. Environ. Sci. Pollut. Res. Int. 21:12843-12855.
Livak, K. J. \& T. D. Schmittgen. 2001. Analysis of relative gene expression data using real-time quantitative PCR and the $2^{-\Delta \Delta C T}$ method. Methods 25:402-408.

Lowe, D. M. \& R. K. Pipe. 1994. Contaminant induced lysosomal membrane damage in marine mussel digestive cells: an in vitro study. Aquat. Toxicol. 30:357-365.

Maisano, M., T. Cappello, A. Natalotto, V. Vitale, V. Parrino, A. Giannetto, S. Oliva, G. Mancini, S. Cappello, A. Mauceri \& S. Fasulo. 2017. Effects of petrochemical contamination on caged marine mussels using a multi-biomarker approach: histological changes, neurotoxicity and hypoxic stress. Mar. Environ. Res. 128:114-123.

Mamaca, E., R. K. Bechmann, S. Torgrimsen, E. Aas, A. Bjørnstad, T. Baussant \& S. L. Floch. 2005. The neutral red lysosomal retention assay and comet assay on haemolymph cells from mussels (Mytilus edulis) and fish (Symphodus melops) exposed to styrene. Aquat. Toxicol. 75:191-201.

Marigomez, I., M. Mugica, U. Izagirre \& I. M. Sokolova. 2017. Chronic environmental stress enhances tolerance to seasonal gradual warming in marine mussels. PLoS One 12:e174359.

Matozzo, V., V. Bertin, M. Battistara, A. Guidolin, L. Masiero, I. Marisa \& A. Orsetti. 2016. Does the antibiotic amoxicillin affect haemocyte parameters in non-target aquatic invertebrates? The clam Ruditapes philippinarum and the mussel Mytilus galloprovincialis as model organisms. Mar. Environ. Res. 119:51-58.

McCallum, E. S., A. P. H. Bose, T. R. Warriner \& S. Balshine. 2017. An evaluation of behavioural endpoints: the pharmaceutical pollutant fluoxetine decreases aggression across multiple contexts in round goby (Neogobius melanostomus). Chemosphere 175:401-410.

Mennigen, J. A., W. E. Lado, J. M. Zamora, P. Duarte-Guterman, V. S. Langlois, C. D. Metcalfe, J. P. Chang, T. W. Moon \& V. L. Trudeau. 2010. Waterborne fluoxetine disrupts the reproductive axis in sexually mature male goldfish, Carassius auratus. Aquat. Toxicol. 100:354-364.

Moore, M. N., J. Icarus Allen \& A. McVeigh. 2006. Environmental prognostics: an integrated model supporting lysosomal stress responses as predictive biomarkers of animal health status. Mar. Environ. Res. 61:278-304.

Mugica, M., I. M. Sokolova, U. Izagirre \& I. Marigomez. 2015. Seasondependent effects of elevated temperature on stress biomarkers, energy metabolism and gamete development in mussels. Mar. Environ. Res. 103:1-10.

Nagasawa, K., N. Treen, R. Kondo, Y. Otoki, N. Itoh, J. M. Rotchell \& M. Osada. 2015. Molecular characterization of an estrogen receptor and estrogen-related receptor and their autoregulatory capabilities in two Mytilus species. Gene 564:153-159.

Negri, A., C. Oliveri, S. Sforzini, F. Mignione, A. Viarengo \& M. Banni. 2013. Transcriptional response of the mussel Mytilus galloprovincialis (Lam.) following exposure to heat stress and copper. PLoS One 8:e66802.

Ni, J. B., Z. Zeng, D. Z. Kong, L. Hou, H. Q. Huang \& C. H. Ke. 2014. Vitellogenin of Fujian oyster, Crassostrea angulata: synthesized in the ovary and controlled by estradiol-17 beta. Gen. Comp. Endocrinol. 202:35-43.

Niemuth, N. J., R. Jordan, J. Crago, C. Blanksma, R. Johnson \& R. D. Klaper. 2014. Metformin exposure at environmentally relevant concentrations causes potential endocrine disruption in adult male fish. Environ. Toxicol. Chem. 34:291-296.

Niemuth, N. J. \& R. D. Klaper. 2015. Emerging wastewater contaminant metformin causes intersex and reduced fecundity in fish. Chemosphere 135:38-45.

Oosterhuis, M., F. Sacher \& T. L. ter Laak. 2013. Prediction of concentration levels of metformin and other high consumption pharmaceuticals in wastewater and regional surface water based on sales data. Sci. Total Environ. 442:380-388. 
Osada, M., M. Harata, M. Kishida \& A. Kijima. 2004. Molecular cloning and expression analysis of vitellogenin in scallop, Patinopecten yessoensis (bivalvia, mollusca). Mol. Reprod. Dev. 67:273-281.

Papageorgiou, M., C. Kosma \& D. Lambropoulou. 2016. Seasonal occurrence, removal, mass loading and environmental risk assessment of 55 pharmaceuticals and personal care products in a municipal wastewater treatment plant in Central Greece. Sci. Total Environ. 543:547-569.

Patra, R. W., J. C. Chapman, R. P. Lim, P. C. Gehrke \& R. M. Sunderam. 2015. Interactions between water temperature and contaminant toxicity to freshwater fish. Environ. Toxicol. Chem. 34:1809-1817.

Péry, A. R. R., M. Gust, B. Vollat, R. Mons, M. Ramil, G. Fink, T. Ternes \& J. Garric. 2008. Fluoxetine effects assessment on the life cycle of aquatic invertebrates. Chemosphere 73:300-304.

Rice, S., L. Pellatt, K. Ramanathan, S. A. Whitehead \& H. D. Mason. 2009. Metformin inhibits aromatase via an extracellular signalregulated kinase-mediated pathway. Endocrinology 150:4794-4801.

Scheurer, M., A. Michel, H.-J. Brauch, W. Ruck \& F. Sacher. 2012. Occurrence and fate of the antidiabetic drug metformin and its metabolite guanylurea in the environment and during drinking water treatment. Water Res. 46:4790-4802.

Scheurer, M., F. Sacher \& H.-J. Brauch. 2009. Occurrence of the antidiabetic drug metformin in sewage and surface waters in Germany. J. Environ. Monit. 11:1608-1613.

Scott, A. P. 2012. Do mollusks use vertebrate sex steroids as reproductive hormones? Part I: critical appraisal of the evidence for the presence, biosynthesis and uptake of steroids. Steroids 77:1450-1468.

Sforzini, S., M. N. Moore, C. Oliveri, A. Volta, A. Jha, M. Banni \& A. Viarengo. 2018. Role of mTOR in autophagic and lysosomal reactions to environmental stressors in molluscs. Aquat. Toxicol. 195:114-128.

Trautwein, C., J.-D. Berset, H. Wolschke \& K. Kümmerer. 2014. Occurrence of the antidiabetic drug metformin and its ultimate transformation product guanylurea in several compartments of the aquatic cycle. Environ. Int. 70:203-212.

Trautwein, C. \& K. Kümmerer. 2011. Incomplete aerobic degradation of the antidiabetic drug metformin and identification of the bacterial dead-end transformation product guanylurea. Chemosphere 85:765-773.

Tyler, C. R. \& R. M. Goodhead. 2010. Impacts of hormone-disrupting chemicals on wildlife. In: Maclean, N., editor. Silent summer: the state of wildlife in Britain and Ireland. Cambridge, UK: Cambridge University Press. pp. 125-140

Widdows, J. 1973. Effect of temperature and food on the heart beat, ventilation rate and oxygen uptake of Mytilus edulis. Mar. Biol. 20:269-276

Wu, L., X.-J. Huang, C.-H. Yang, S.-S. Deng, M. Qian, Y. Zang \& J. Li. 2011. 5'-AMP-activated protein kinase (AMPK) regulates progesterone receptor transcriptional activity in breast cancer cells. Biochem. Biophys. Res. Commun. 416:172-177.

Yang, L., J. T. He, S. H. Su, Y. F. Cui, D. L. Huang \& G. C. Wang. 2017. Occurrence, distribution, and attenuation of pharmaceuticals and personal care products in the riverside groundwater of the Beiyun River of Beijing, China. Environ. Sci. Pollut. Res. Int. 24:15838-15851.

Zorita, I., M. Ortiz-Zarragoitia, M. Soto \& M. P. Cajaraville. 2006. Biomarkers in mussels from a copper site gradient (Visnes, Norway): an integrated biochemical, histochemical and histological study. Aquat. Toxicol. 78:S109-S116. 